\title{
ANALISIS FAKTOR PENYEBAB KESULITAN BELAJAR MATEMATIKA PADA SISWA SDN 01 NANGA KANTUK
}

\author{
Andri $^{1}$, Olenggius Jiran Dores ${ }^{2}$, Anastasia Helina Lina ${ }^{3}$ \\ ${ }^{1,2}$ Prodi Pendidikan Matematika, STKIP Persada Khatulistiwa Sintang \\ ${ }^{3}$ Prodi PGSD, STKIP Persada Khatulistiwa Sintang \\ e-mail: $\underline{1}$ andry tkr@yahoo.com, ${ }^{2}$ olenggius@gmail.com,$\underline{{ }^{3} \text { lenasintang@gmail.com }}$
}

\begin{abstract}
The study aimed to determine the factors that cause difficulty learning mathematics students in State Elementary School 01 Nanga Kantuk Academic Year 2018/2019. The study population was all 121 students in SDN 01 Nanga Kantuk and the sample of 55 students used Purposive Sampling techniques, consisting of classes IV, V and VI. The approach in this study is quantitative with the method of factor analysis and descriptive analysis, while the form of this study is exploratory factor analysis. The results of factor analysis found 5 clustering factors that affect learning difficulties named interest factors with a percentage of 28,997\% variance, teacher factors with a percentage of $14,386 \%$, learning habits factors with a percentage of $9,860 \%$, family environment factors at $9,860 \%$ and home atmosphere factors with variance percentage of 7.290\%. While the most dominant factors affect learning difficulties are interest factors with a percentage of variance of $28.997 \%$.
\end{abstract}

Keyword: Factor Analysis, Learning Difficulties, Mathematics

\begin{abstract}
Abstrak. Penelitian ini bertujuan untuk mengetahui faktor penyebab kesulitan belajar matematika siswa di Sekolah Dasar Negeri 01 Nanga Kantuk Tahun Pelajaran 2018/2019. Populasi penelitian adalah seluruh siswa di SDN 01 Nanga Kantuk sebanyak 121 orang dan yang dijadikan sampel sebanyak 55 orang menggunakan teknik Sampling Purposive, terdiri dari kelas $I V, V$ dan VI. Pendekatan pada penelitian ini kuantitatif dengan metode analisis faktor dan analisis deskriptif, sedangkan bentuk penelitian ini adalah analisis faktor eksploratori. Hasil analisis faktor ditemukan 5 faktor yang mengelompok yang mempengaruhi kesulitan belajar yang diberi nama faktor minat dengan persentase variance $28.997 \%$, faktor guru dengan persentase $14.386 \%$, faktor kebiasaan belajar dengan persentase $9.860 \%$, faktor lingkungan keluarga dengan persentase $9.860 \%$ dan faktor suasana rumah dengan persentase varians $7.290 \%$. Sedangkan faktor yang paling dominan mempengaruhi kesulitan belajar yaitu faktor minat dengan persentase varians $28,997 \%$.
\end{abstract}

Kata Kunci: Analisis Faktor, Kesulitan Belajar, Matematika. 


\section{PENDAHULUAN}

Pendidikan bagi kehidupan manusia merupakan kebutuhan mutlak yang harus dipenuhi sepanjang hayat. Tanpa pendidikan mustahil suatu kelompok manusia dapat hidup sejalan dengan cita-cita untuk maju, sejahtera dan bahagia menutut konsep pandangan hidup mereka. Untuk memajukan kehidupan itu, maka pendidikan menjadi sarana utama yang perlu di kelola, secara sistematis dan konsisten berdasarkan pandangan teoretikal dan praktikal sepanjang waktu sesuai dengan lingkungan hidup manusia itu sendiri (Ihsan, 2011: 2). Namun dalam dunia pendidikan kerap kali siswa mengalami hambatan salah satunya kesulitan dalam belajar. Kesulitan belajar yang sering di jumpai di Sekolah Dasar yaitu kesulitan belajar matematika, karena banyak orang yang masih memandang matematika sebagai bidang studi yang paling sulit (Abdurrahman, 2012).

$$
\text { Abdurrahman (2010: 9-11) }
$$
berpendapat bahwa kesulitan belajar dapat berwujud sebagai suatu kekurangan dalam satu atau lebih bidang akademik, baik dalam mata pelajaran yang spesifik seperti membaca, menulis, matematika, dan mengeja. Menurut Syah (2009: 184), kesulitan belajar yang dialami siswa disebabkan oleh berbagai faktor secara garis besar, faktor-faktor penyebab timbulnya kesulitan belajar terdiri dari dua macam, yakni: Faktor intern siswa, meliputi gangguan atau kekurangmampuan psiko-fisik, yakni: 1) bersifat kognitif seperti intelegensi siswa; 2) bersifat afektif seperti labihnya emosi dan sikap; 3) bersifat psikomotor seperti terganggunya alat indera penglihatan dan pendengaran. Faktor eksternal meliputi semua situasi dan kondisi lingkungan sekitar yang tidak mendukung aktivitas belajar siswa. Faktor lingkungan ini antara lain: 1) Lingkungan keluarga seperti ketidakharmonisan hubungan antara ayah dan ibu; 2) lingkungan masyarakat seperti teman sepermainan yang nakal; 3) lingkungan sekolah seperti kondisi guru dan alat-alat belajar yang berkualitas rendah.

Menurut Hamalik (Syah, 2009) faktor faktor kesulitan belajar sebagai berikut yang bersumber dari diri sendiri diantaranya: Kurangnya minat terhadap bahan pelajaran, Minat yang besar akan mendorong motivasinya, demikian pula dalam mengikuti pelajaran di sekolah. Kurangnya minat menyebabkan kurangnya perhatian dan usaha belajar, sehingga menghambat belajar. Tentu saja berpengaruh pada hasil belajar. Kesehatan yang sering terganggu badanyang sering sakit-sakitan, kurangnya tenaga, kurang vitamin, merupakan faktor yang bisa menghambat belajar seseorang. Adanya gangguan emosional, rasa tak tenang, khawatir, mudah tersinggung, sikap agresif, gangguan dalam proses berpikir, semuanya menjadikan kegiatan belajar terganggu. Kecakapan mengikuti pelajaran. Cakap mengikuti pelajaran tidak sama dengan terusmenerus mengikuti pelajaran. Disebut cakap, apabila ia mengerti hal yang diajarkan dan kemudian merangsangnya menambah 
pengetahuan yang luas. Untuk bisa memahami dan isi pelajaran diperlukan perhatian yang terkonsentrasi dan mengikuti proses pembelajaran dengan baik serta mengulangnya di luar jam pelajaran. Kebiasaan belajar Setiap orang mempunyai kebiasaan belajarnya sendiri-sendiri. Ada yang bisa belajar pada malam hari dan juga ada yang belajar pada siang hari. Kebiasaan belajar ini bersifat individual, tidak bisa ditentukan sama rata untuk setiap orang. Akan tetapi, tentu saja sebenarnya tidak boleh terikat pada kebiasaan-kebiasaan itu, dan juga tidak boleh menganut kebiasaan yang tidak teratur, tidak menetu.

Menurut Setyono (2007: 1) matematika adalah salah satu ilmu yang sangat penting dalam dan untuk hidup kita. Banyak hal di sekitar kita yang selalu berhubungan dengan matematika. Mencari nomor rumah seseorang, menelepon, jual beli barang, menukar uang, mengukur jarak dan waktu. Untuk mengatasi kesulitan belajar matematika tersebut perlunya kerja sama antar anggota tim baik dari guru dan siswa sangatlah diperlukan dalam penaggulangan kesulitan belajar matematika agar kesulitan tersebut dapat teratasi. Menurut Saud (2009: 32) tugas dan tanggung jawab guru sebagai pembimbing sangatlah penting dalam memberikan bantuan kepada siswa memecahkan masalah yang dihadapinya, karena tugas seorang guru tidak hanya berkenaan dengan penyampaian ilmu pengetahuan saja, melainkan juga menyangkut pembinaan kepribadian dan pembentukan nilai-nilai siswa.
Pendapat diatas sejalan dengan hasil observasi awal pada tanggal 5 februari sampai tanggal 9 februari 2018 di SDN 01 Nanga Kantuk, siswa kelas III, IV dan V yang sekarang sudah naik ke kelas IV, V dan VI merasa kesulitan belajar pada mata pelajaran matematika, hal ini di buktikan dengan daftar nilai ulangan murni yang masih rendah, banyak siswa belum memenuhi kriteria ketuntasan minimal (KKM) yang sudah di tentukan yaitu 62. Siswa kelas IV berjumlah 19 orang hanya 4 siswa sajayang tuntas dengan nilai rata-rata 44 , untuk siswa kelas $\mathrm{V}$ berjumlah 18 orang yang mencapai ketuntasan hanya 5 siswa saja dengan nilai rata-rata 56, sedangkan untuk siswa kelas VI yang berjumlah 18 orang $100 \%$ tidak tuntas dengan nilai rata-rata 32,08. Melihat masalah tersebut peneliti melakukan pengamatan dan wawancara dengan kepala sekolah, guru matematika IV, V, VI dan melakukan wawancara juga dengan siswa. Dari hasil pengamatan serta wawancara tersebut peneliti beranggapan faktor penyebab kesulitan belajar matematika di karenakan beberapa faktor seperti faktor dari siswa itu sendiri, faktor guru, dan faktor lingkungan keluarga.

Faktor dari siswa yaitu kurangnya minat dalam belajar matematika terlihat ketika proses belajar mengajar berlangsung siswa sibuk bermain dengan teman tidak mendengarkan atau memperhatikan penjelasan dari guru, selain itu lemahnya integensi dibuktikan ada siswa yang memperhatikan penjelasan dari guru tetapi ketika diberikan soal lamban dalam memahaminya, faktor lain seperti kebiasaan 
belajar yang kurang teratur dibuktikan hanya mengandalkan belajar saat di sekolah saja dan saat tiba di rumah tidak pernah belajar.

Sedangkan faktor dari guru yaitu kurangnya penggunaan media yang dapat mendukung atau memperjelas materi supaya siswa mudah memahami materi yang disampaikan. Selain media, metode yang digunakan guru saat mengajar juga kurang bervariasi sehingga siswa cepat meras jenuh. Guru cenderung duduk di bangku saja ketika sudah memberikan contoh soal dan tugas guru meninggalkan siswa sendiri didalam kelas, akibatnya siswa sulit untuk bertanya tentang hal-hal yang kurang dipahami.

Faktor lingkungan keluarga seperti orangtua yang tidak pernah mengingatkan anaknya untuk belaja, tidak pernah membimbing anak belajar saat di rumah. Pendapat ini sejalan dengan pendapat Syah (2009: 184) yang mengatakan faktor yang menyebabkan timbulnya kesulitan belajar seperti integensi, sikap, alat indera, kurangnya minat terhadap bahan pelajaran, kesehatan yang sering terganggu, kecakapan mengikuti pelajaran dan kebiasaan belajar. Sedangkan menurut Wahyuni (2008: 20) faktor eksternal penyebab kesulitan belajar diantaranya faktor dari guru, metode pelajaran, alat pelajaran yang kurang, disiplin sekolah, faktor lingkungan keluarga seperti relasi antar anggota keluarga dan suasana rumah yang tidak nyaman untuk belajar, untuk mengatasi masalah tersebut peran guru sangatlah diperlukan. Sebagaicalon pendidik guru sekolah dasar sangatlah penting untuk mengetahui kesulitan belajar yang sering dialami oleh peserta didiknya supaya dapat cepat mencari solusi atas permasalahan tersebut, khususnya pada pelajaran matematika yang masih dianggap pelajaran yang sangat sulit bagi siswa. Diharapkan dengan mengetahui penyebab kesulitan belajar tersebut dan dapat menemukan solusi yang tepat nilai belajar matematika siwa meningkatkan.

Tujuan pada penelitian ini yaitu mendeskripsikan faktor-faktor yang mempengaruhi dan faktor paling dominan penyebab kesulitan belajar matematika siswa di Sekolah Dasar Negeri 01 Nanga Kantuk Tahun Pelajaran 2018/2019.

\section{METODE}

Penelitian ini peneliti menggunakan metode analisis faktor dan analisis deskriptif untuk . Menurut Supranto (2004: 114) analisis faktor merupakan nama umum yang menunjukan suatu kelas prosedur, utamanya digunakan untuk mereduksi data atau meringkas dari variabel yang banyak diubah menjadi sedikit variabel. Metode deskriptif adalah metode yang digunakan untuk menganalisa data dengan cara mendeskripsikan atau menggambarkan data yang telah terkumpul sebagaimana adanya tanpa bermaksud membuat kesimpulan yang berlaku untuk umum atau generalisasi ( Sugiyono, 2015: 147).

Penelitian ini menggunakan bentuk penelitian analisis faktor eksploratori (ekploratory faktor analysis). Menurut Widarno (2015: 193) analisis faktor 
eksploratori merupakan analisis faktor yang mencari sejumlah indikator untuk membentuk faktor umum (common factor) tanpa ada landasan teori sebelumnya. Dengan kata lain analisis faktor eksploratori merupakan sebuah metode untuk membangun sebuah teori (theory building).

Populasi pada penelitian ini adalah seluruh siswa di SDN 01 Nanga Kantuk sebanyak 121 orang, sedangkan sampel yang digunakan sebanyak 55 orang yaitu kelas IV, V dan VI. Teknik pengambilan sampel Non Probability Sampling. Menurut Sugiyono (2015: 84) Non Probability Sampling adalah teknik pengembilan sampel yang tidak memberikan peluang/kesempatan yang sama bagi setiap unsur atau anggota populasi untuk dijadikan sampel. Sedangkan teknik Sampling purposive adalah teknik penentuan sampel dengan pertimbangan tertentu. Menurut Arikunto (2013: 174) sampel adalah sebagian atau wakil populasi yang akan diteliti. Sedangkan menurut Sugiyono (2013: 62) sampel adalah bagian dai jumlah dan karakteristik yang dimiliki oleh populasi.

Teknik pengumpulan data pada penelitian ini yaitu teknik kuisioner (angket), dan teknik dokumentasi. Instrumen pengumpul data pada penelitian ini lembar angket dan dokumen.

\section{HASIL DAN PEMBAHASAN}

Hasil pada penelitian ini item pertanyaan yang dinyatakan Valid dan Reliabel melalui uci coba angket ada 32 item penyataan angket yang valid. Hasil reliabilitas 0.924 artinya kriteria yang diperoleh sangat tinggi. Setelah dilakukan pengumpulan data dan dianalsis dengan analisi faktor eksploratori. Langkah pertama memilih variabel. Ketika memilih variabel ditemukan 18 variabel yang nilai Anti Image corelation> 0.5 kemudian faktor yang mengelompok harus di ekstraksi dan ditemukan 18 variabel yang mampu membentuk faktor baru. Setelah di ekstraksi selanjutnya langkah ketigaditemukan 5 faktor baru yang membentuk dimana nilai eigenvalue $>1$. Langkah faktor ke empat yaitu rotasi faktor ditemukan ada 4 variabel mengelompok pada faktor pertama dengan persentase variance $28.887 \%, 4$ variabel mengelompok pada faktor kedua dengan persentase variance $14.386 \%$, 6 variabel menglompok pada faktor ke tiga dengan persentase variance $11.451 \%, 2$ variabel mengelompok pada faktor ke empat dengan persentase variance $9.860 \%$, dan 2 variabel mengelompok pada faktor ke lima dengan persentase variance 7.290. Total terdapat 18 variabel yang mengelompok menjadi 5 faktor baru dengan jumlah persentase variance 71.984\%. Langkah kelima pemberian nama pada faktor baru. Berdasarkan hubungan antar variabel peneliti memberi nama 'Faktor Minat' untuk faktor pertama, 'Faktor Guru' untuk faktor ke dua, 'Faktor Kebiasaan Belajar' untuk faktor ke tiga, 'Faktor Lingkungan Keluarga' untuk faktor ke empat dan 'Faktor Suasana Rumah' untuk faktor ke lima. Adapun uraian kelima faktor tersebut sebagai berikut:

\section{Faktor Minat}

Hasil ekstrak dan rotasi dengan analisis faktor untuk faktor yang pertama ditemukan 4 item penyataan yang tergabung 
dalam faktor pertama dengan presntase varians 28.997\%. Adapun pemberian nama faktor berdasarkan item soal yang mengelompok saling berhubungan dan diberi nama 'Faktor Minat'. Dinami faktor minat dikarenakan hasil muatan faktor dari V2, V15, V18, V31 saling berhubungan. Siswa yang kurang berminat mengikuti pelajaran matematika ditambah tidak serius mengikuti proses belajar mengajar didalam kelas seperti pandangan selalu keluar kelas apabila guru matematika menjelaskan materi pelajaran akan berdampak bagi siswa itu sendiri yaitu mudah putus asa dalam mengerjakan soal latihan apabila da soal yang kurang dipahami.

Hasil muatan faktor sejalan dengan pendapat Hamalik (Syah, 2009) menjelaskan kurangnya minat menyebabkan kurangnya perhatian dan usaha belajar, sehingga menghambat belajar dan tentunya berdampak pada hasil belajar. Minat yang besar akan mendorong motivasi dalam mengikuti pelajaran di sekolah. Berdasarkan pendapat diatas dapat disimpulkan bahwa minat yang kurang pada diri seorang siswa dapat menyebabkan kurangnya perhatian seperti yang terjadi di SDN 01 Nanga Kantuk, kurangnya ketertarikan dan kurangnya usaha belajar terhadap suatu kegiatan sehinggaberdampak pada nilai matematika yang rendah.

\section{Faktor Guru}

Hasil ekstrak dan rotasi dengan analisis faktor untuk faktor yang kedua ditemukan 4 item penyataan yang tergabung dengan presentase varians $14.386 \%$.
Pemberian nama faktor berdasarkan hubungan antar item peryataan tersebut dan diberi nama 'Faktor Guru'. Dinamai faktor guru dikarenakan hasil muatan ke empat variabel saling berhubungan.

Peranan guru menurut Suparlan (2005:25), status guru mempunyai implikasi terhadap peran dan fungsi yang menjadi tanggung jawabnya. Guru memiliki satu kesatuan peran dan fungsi yang tidak terpisahkan, antara kemampuan mendidik, membimbing, mengajar, dan melatih. Keempat kemampuan tersebut merupakan kemampuan integratif, antara yang satu dengan yang lain tidak dapat dipisahkan.

Guru yang terlihat galak oleh siswa ditambah hanya menggunakan metode yang sama pada saat mengajar tidak pernah dibantu oleh alat peraga saat memberi penjelasan materi membuat siswa merasa takut dan pembelajaran manjadi membosankan. Pada saat peneliti melakukan observasi awal kondisi guru yang diceritakan responden sesuai dengan keadaan yang terjadi yaitu guru sering memberi hukuman kepada siswa yang tidak bisa menjawab, satu soal salah siswa akan mendapat satu kali pukulan kayu, jika dua soal yang salah siswa akan mendapat dua kali pukulan kayu, begitu seterusnya. Guru juga hanya menggunakan metode ceramah ketika ditanya guru menjawab faktor usia dan waktu, guru tidak sempat dalam membuat media pembelajaran. Akibat perbuatan guru seperti ini membuat siswa kurang berminat bahkan merasa takut apabila ada pelajaran matematika. 


\section{Faktor Kebiasaan Belajar}

Hasil ekstrak dan rotasi dengan analisis faktor untuk mengetahui faktor ketiga terwakilkan 6 item penyataan dengan varians $11.451 \%$. Item penyataan yang mengelompok cukup sulit menentukan nama yang akan diberikan sebagai konsep baru. Pemeberian nama tersebut berdasarkan adanya keterkaitan satu sama lain dan akhirnya diberi nama 'Faktor Kebiasaan Belajar'.

Akibat cara belajar anak yang kurang tepat hanya mengandalkan belajar di sekolah dan belajar pada saat mau ulangan maka berdampak padah hasil belajar anak yang rendah. Kebiasaan belajar merupakan salah satu faktor dari beberapa faktor yang dapat mempengaruhi belajar, hal ini seperti yang diungkapkan oleh Slameto (2010 : 82-83) "kebiasaan belajar juga akan mempengaruhi belajar itu sendiri" kebiasaan belajar yang dapat mempengaruhi keberhasilan studi adalah kebiasaan belajar yang baik, sedangkan yang membuat individu gagal adalah karena melaksanakan kegiatan belajar yang buruk.

Oleh karena itu seharusnya siswa memiliki cara belajar yang teratur supaya selalu mengingat materi yang telah disampaikan oleh guru tentunya hasil belajar anak akan menjadi lebih baik. Jika dilihat dari kehidupan sehari-hari siswa di Nanga Kantuk lebih banyak waktu bermain bersama teman dari pada belajar.

\section{Faktor Lingkungan Keluarga}

Hasil ekstrak dan rotasi dengan analisis faktor untuk mengetahui faktor keempat terwakilkan oleh 2 item penyataan dengan presentase $9.860 \%$. Pemberian nama faktor berdasarkanketerkaitan satu sama lain dan diberi nama 'Faktor Lingkungan Keluarga'. Faktor lingkungan keluarga yang dimaksud dan terjadi di Nanga Kantuk seperti orang tua yang sibuk ke ladang, sibuk berkebun, sibuk pergi ke sawit, menoreh, sibuk pergi ke kantor.

Mayoritas pekerjaan orang tua siswa di nanga Kantuk yaitu petani dan pekerja sawit. Berangkat petang (dini hari) pulang sudah sore hari bahkan malam hari. Akibatnya dikarnakan keadaan orang tua yang sudah lelah bekerja seharian tidak sempat lagi dalam mendampingi anaknya belajar ditambah memang ada orang tua siswa yang tidak pernah menempuh bangku pendidikan sehingga tidak paham mengajari anaknya atau membantu anaknya dalam menyelesaikan soal yang anak tidak mengerti. Untuk siswa sendiri tidak sedikit juga siswa yang pulang sekolah membantu orang tuanya bekerja diladang dan pulang sudah petang, kondisi tubuh siswa yang lelah tidak memungkinkan untuk belajar.

Hasbullah (2011: 38) yang menyatakan bahwa "lingkungan keluarga merupakan lingkungan utama dan pertama bagi anak, karena dalam keluarga inilah anak pertama-tama mendapat didikan dan bimbingan dan dikatakan sebagai lingkungan yang utama karena sebagian besar dari kehiduppan anak adalah didalam keluarga". Keluarga memegang peranan penting dalam menunjang keberhasilan belajar anak, seperti yang dinyatakan Slameto (2010: 60-64) "Siswa akan menerima pengaruh dari keluarga 
berupa: cara orang tua mendidik, relasi antara anggota keluarga, suasana rumah tangga, keadaan ekonomi keluarga, pengertian orang tua, dan latar belakang kebudayaan".

\section{Faktor Suasana Rumah}

Hasil ekstrak dan rotasi dengan analisis faktor untuk faktor kelima terwakilkan oleh 3 item penyataan dengan presentase $7.290 \%$. Pemberian nama faktor berdasarkan keterkaitan satu sama lain. Menurut Subini (2011: 33) suasana rumah sangat mempengaruhi hasil dan prestasi belajar. Suasana rumah yang gaduh, bising, dan semeraut tidak akan memberikan ketenangan terhadap diri anak untuk belajar.

Suasana rumah yang mempengaruhi kesulitan belajar anak di Nanga kantuk seperti rumah terlalu banyak anggota keluarga yang tinggal didalamnya mengakibatkan susah untuk belajar, rumah yang dekat dengan jalan raya akibatnya banyak kendaraan yang mondar mandir, selain itu suasana rumah yang dekat dengan perusahaan sawit, anak ikut orang tua tinggal di perkebunan sawit suasananya selalu ramai dengan pekerja yang bekerja di sekitar lingkungan itu, ditambah pada malam hari kurang penerangan dikebun sawit, itu semua akan berdampak bagi anak susah untuk belajar dengan baik.

Untuk Hasil analisis distribusi frekuensi masing-masing faktor yang mempengaruhi kesulitan belajar matematika siswa di SDN 01 Nanga Kantuk adalah sebagai berikut: faktor minat, responden yang menjawab setuju sebesar $60.2 \%$ dan tidak setuju sebesar $25.4 \%$. dapat dilihat besarnya presentase pada gambar di bawah ini:

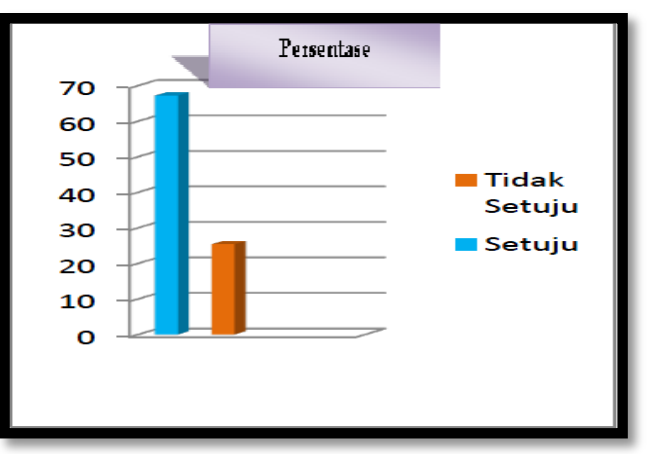

Gambar 1. Persentase Variance Faktor Minat

Faktor ke dua yaitu faktor guru, responden yang menjawab setuju sebesar $57.4 \%$ dan tidak setuju sebesar 33\%. Hasil persentase faktor guru dapat dilihat pada gambar di bawah ini:

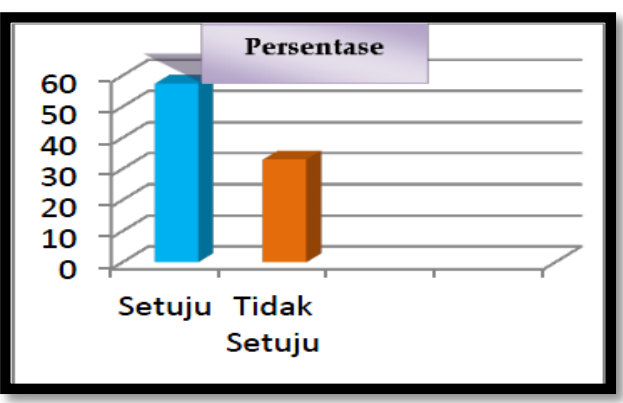

Gambar 2. Persentase Variance Faktor Guru

Faktor ke tiga yaitu faktor kebiasaan belajar, responden yang menjawab setuju sebesar $70.9 \%$ dan tidak setuju sebesar $27 \%$. Hasil persentase faktor kebiasaan belajar dapat dilihat pada gambar di bawah ini:

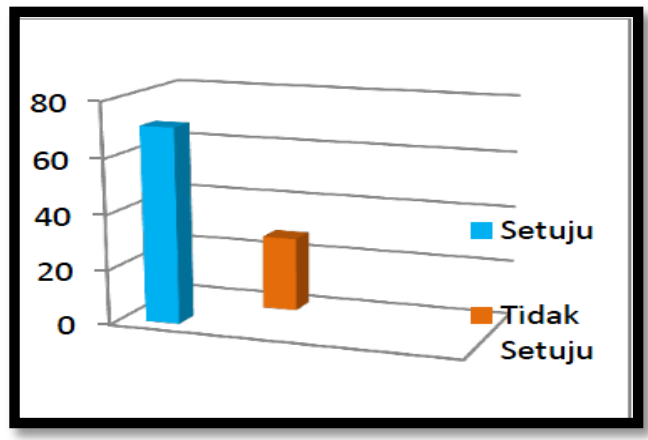

Gambar 3. Persentase Variance Faktor Kebiasaan Belajar

Faktor ke empat yaitu faktor lingkungan keluarga, responden yang 
menjawab setuju sebesar $77.8 \%$ dan tidak setuju sebesar 9.5\%. hasil presentase dapat dilihat pada gambar di bawah ini:

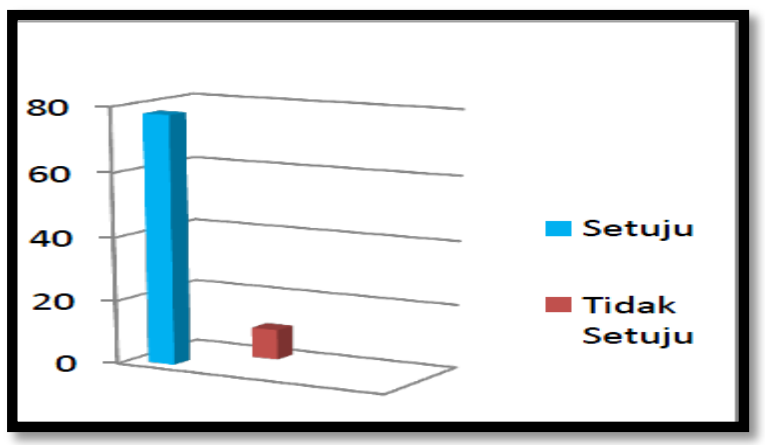

Gambar 2. Persentase Variance Faktor Lingkungan Keluarga

Faktor ke lima yaitu faktor suasana

rumah, responden yang menjawab setuju sebesar $67.4 \%$ dan tidak setuju $29.2 \%$. hasil persentasefaktor suasana rumah dapat dilihat pada gambar di bawah ini:

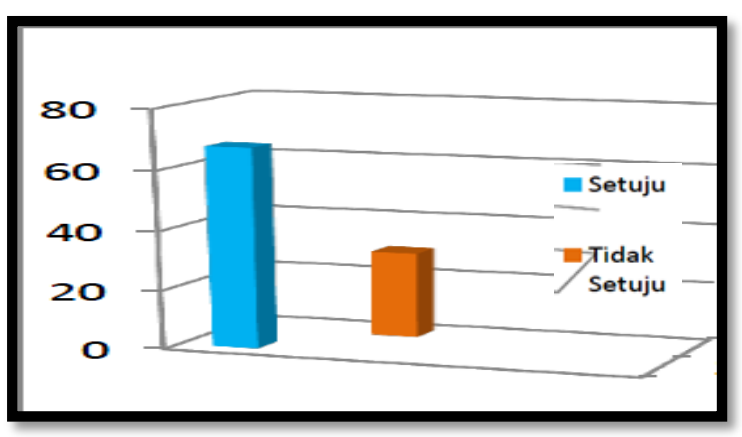

Gambar 2. Persentase Variance Faktor Susana Rumah

\section{SIMPULAN (PENUTUP)}

Berdasarkan analisis data dan jawaban dari rumusan masalah pada penelitian ini. Faktorfaktor Penyebab Kesulitan Belajar Matematika Siswa di Sekolah Dasar Negeri 01 Nanga Kantuk Tahun Pelajaran 2018/2019 berdasarkan hasil temuan diberi nama faktor minat, faktor guru, faktor kebiasaan belajar, faktor lingkungan keluarga dan faktor suasana rumah dengan total persentase varians 71.984\%. sedangkan faktor yang dominan mempengaruhi Kesulitan Belajar Matematika
Siswa di Sekolah Dasar Negeri 01 nanga Kantuk Tahun Pelajarab 2018/2019 yaitu 'Faktor Minat" dengan total variance $28.997 \%$.

Adapun saran dalam penelitian ini yang pertama saran bagi guru alangkah baiknya menggunakan metode yang lebih bervariasi dalam mengajar matematika di dalam kelas, lebih mendekatkan diri dengan siswa agar mengetahui kesulitan apa saja yang dirasakan siswa pada saat belajar matematika. Sebisa mungkin guru matematika bisa menjadikan suasanna di dalam kelas nyaman untuk belajar tanpa ada rasa takut. Saran yang kedua bagi orang tua dan keluarga hendaknya mendampingi dan selalu mengingatkan anaknya belajar ketika berada di rumah. Saran yang ketiga yaitu untuk siswa itu sendiri alangkah baiknya membuat jadwal belajar agar waktu belajar lebih teratur, harus bisa memusatkan perhatian kepada guru matematika ketika guru memberi penjelasan di depan kelas sehingga siswa akan lebih mudah memahami isi dari penjelasan yang di sampaikan oleh guru. Lebih bergaul dengan teman yang bisa membawa dapak positif seperti teman yang rajin belajar kelompok sehingga akkan berdampak pada hsil belajar yang lebih baik. Perbanyak waktu belajar dari pada bermain dan menonton televisi pada saat berada di luar sekolah.

\section{DAFTAR PUSTAKA}

Abdurahman, Maman. dan Muhiddin. 2017. Analisis Korelasi, Regresi, dan Jalur dalam Penelitian. Bandung: Pustaka Setia. 
Abdurrahman, Mulyono. 2010. Pendidikan Bagi Anak Berkesulitan Belajar. Jakarta: Rineka Cipta.

Adurrahman, Mulyono. 2012. Pendidikan Bagi Anak Berkesulitan Belajar. Jakarta: Rineka Cipta.

Andri \& Rismawati, Melinda. 2018. Analisis Faktor-Faktor yang Mempengaruhi Rendahnya Hasil Belajar Konsep Dasar Matematika SD Pada Mahasiswa PGSD. Jurnal Vox Edukasi 9 (2): 91-101

Andri. 2014. Faktor-faktor yang Mempengaruhi Rendahnya MinatMasyarakat terhadap SMP Negeri. Jurnal Pendidikan Humaniora. 2(3): 228-235

Arikunto, Suharsimi. 2013. Prosedur Penelitian Suatu Pendekatan Praktik. Jakarta: Rineka Cipta.

Hasbullah. 2011. Dasar-dasar Ilmu Pendidikan. Jakarta: PT. Rajagrafindo Persada.

Ihsan, Fuad. 2011. Dasar-Dasar Kependidikan. Jakarta: Rineka Cipta.

Muhidin, Sambas Ali., dan Abdurahman, Maman. 2011. Analisis Korelasi, Regresi, dan Jalur dalam Penelitian. Bandung: Pustaka Setia.

Saud,Udin Syafudin. 2009. Pengembangan Profesi Guru. Bandung: Alfabeta.

Setyono, Ariesandi. 2007. Mathemagics. Jakarta: PT Gramedia Pustaka Utama.

Slameto.2010. Belajar Dan Faktor-Faktor Yang Mempengaruhinya. Jakarta: Rineka Cipta.

Sugiyono. 2013. Metode Penelitian Pendidikan Pendekatan Kuantitatif, kualitatif, dan $R \& D$. Bandung: Alfabeta.

Sugiyono. 2015. Metode Penelitian Pendidikan Pendekatan Kuantitatif, Kualitatif, dan R\&D. Bandung:
Alfabeta.

Suparlan. 2005. Menjadi Guru Efektif. Yogyakarta. Hikayat Publishing.

Supranto. 2004. Analisis Multivariat Arti \& Interpretasi. Jakarta: Rineka Cipta.

Syah, Muhibbin. 2009. Psikologi Belajar. Jakarta: Raja Grafindo Indonesia.

Wahyuni, Baharudin. 2008. Teori Belajar dan Pembelajaran.Yogyakarta: Ar-Ruzz Media.

Widarno, Agus. 2015. Analisis Multivariate Terapan.Yogyakarta: UPP STIM YKPN. 